\title{
Aplikasi Pemenuhan Gizi Melalui Pola makan Pada PenderitaTuber Kolosis Paru Berbasis
}

\author{
Android \\ Bianto Aluano, Alwin M. Sambul, Yaulie D. Y. Rindengan \\ Teknik Informatika Universitas Sam Ratulangi. Manado, Indonesia \\ Aluanob@gmail.com, al@unsrat.ac.id, rindengan@unsrat.ac.id
}

\begin{abstract}
Abstrak - Penyakit tuberkulosis masih menjadi masalah kesehatan global dan merupakan penyebab kematian ke dua setelah HIV. Salah satu faktor yang mempengaruhi terjangkitnya penyakit $\mathrm{TB}$ adalah status gizi. Status gizi yang buruk akan meningkatkan resiko terhadap penyakit $\mathrm{TB}$ paru, untuk memenuhi kebutuhan tersebut membutuhkan perhitungan kalori makanan yang cepat dan mudah untuk membantu proses penyembuhan pada pasien yang terkena penyakit TB paru dan untuk memenuhi gizi setiap harinya, maka perlu untuk merancang suatu aplikasi yang bisa membantu masyarakat untuk menentukan pola makan yang baik bagi penderita penyakit tuberkolosis (TB). Skripsi ini berisi tentang proses pembuatan Aplikasi berbasis Android, dimana aplikasi ini membantu pengguna dalam mendapatkan informasi tentang pola makan, lebih khususnya bagi penderita penyakit TBC paru. Baik informasi berupa komposisi makanan, informasi nilai kalori pengguna dan informasi nilai kalori makanan. Aplikasi ini bertujuan untuk membantu masyarakat penderita penyakit tuberkolosis untuk memenuhi asupan gizi dengan cara mengatur pola makan yang baik, begitu juga Masyarakat pada umumnya. Metode yang digunakan dalam pembuatan aplikasi ini adalah $R A D$ (Rapid Application Development) yang meliputi tiga tahap kerja yaitu analisa persyaratan, analisa modeling dan fase konstruksi. Dengan pola makan yang teratur dan bergizi diharapkan dapat membantu masyarakat dalam proses penyembuhan penyakit TBC paru.
\end{abstract}

Kata kunci : Android, kalori makanan, RAD, TBC PARU,

\section{PENDAHULUAN}

Sistem Kesehatan Nasional menyatakan bahwa segala upaya dalam pembangunan kesehatan di Indonesia diarahkan untuk mencapai derajat kesehatan yang lebih tinggi yang memungkinkan orang hidup lebih produktif baik sosial maupun ekonomi. Dengan meningkatnya status sosial ekonomi, pelayanan kesehatan masyarakat, perubahan gaya hidup, bertambahnya umur harapan hidup, maka di Indonesia mengalami pergeseran pola penyakit dari penyakit menular menjadi penyakit tidak menular, hal ini dikenal transisi epidemiologi. Kecenderungan meningkatnya prevalensi penyakit menular salah satunya adalah Tuberkulosis (TB) yang disebabkan oleh kuman Mycobacterium tuberculosis.

Laporan TBC dunia oleh WHO tahun 2006, pernah menempatkan Indonesia sebagai penyumbang terbesar nomor tiga di dunia setelah India dan Cina dengan jumlah kasus baru sekitar 539.000 jiwa dengan jumlah 101.000 jiwa per tahun. Sedangkan pada tahun 2009 Indonesia menduduki peringkat ke lima di dunia setelah India, Cina, South Afrika dan Nigeria dengan jumlah prevalensi 285/100.000 penduduk, sedangkan angka kematian telah turun menjadi 27/100.000 penduduk. Sepertiga dari jumlah tersebut terdapat di sekitar Puskesmas, pelayanan rumah sakit/klinik pemerintah dan swasta, praktik swasta dan sisanya belum terjangkau unit pelayanan kesehatan (Depkes, 2010)

Berdasarkan data Riset Kesehatan Dasar (Riskesdas) 2010, prevalensi TB paru pada pasien yang pernah didiagnosis dengan TB paru yang berada di lima urutan tertinggi yaitu, Papua 1.441 per 100.000 penduduk, Banten 1.282 per 100.000 penduduk, Sulawesi Utara 1.221 per 100.000 penduduk, Gorontalo 1.200 per 100.000 penduduk, dan DKI Jakarta 1.032 per 100.000 penduduk. Adapun lima provinsi dengan prevalensi TB paru tertinggi yang didapatkan berdasarkan gejala klinis yaitu, Gorontalo 6.992 per 100.000 penduduk, Papua Barat 6.722 per 100.000 penduduk, Nusa Tenggara Timur (NTT) 6.511 per 100.000 penduduk, Sulawesi Tengah 5.367 per 100.000 penduduk, dan Jambi 5.337 per 100.000 penduduk.

Tuberkulosis (TB) paru adalah suatu penyakit infeksi yang disebabkan oleh kuman Mycobacterium Tuberculosis. Sumber penularan berasal dari dahak pasien yang mengandung kuman TB. Bakteri ini merupakan bakteri basil yang sangat kuat sehingga memerlukan waktu yang lama untuk mengobatinya. Bakteri ini lebih sering menginfeksi 
organ paru-paru dibandingkan bagian tubuh yang lain (Depkes RI,2002).

TB merupakan penyakit pembunuh utama dimasyarakat dan menjadi masalah kesehatan dimasyarakat. Saat ini diseluruh dunia masih terdapat 8 juta kasus terinfeksi dan 3 juta kasus meninggal dunia setiap tahunnya (Depkes RI,2002). Penurunan berat badan, malaise, dan anoreksia sering terjadi pada penderita TB. Penurunan Berat Badan dapat mencapai 10\%, kondisi penderita TB dapat dipulihkan dengan mengkonsumsi makanan yang bergizi. Pengaturan ini bertujuan untuk memenuhi kebutuhan energi dan protein yang meningkat untuk mencegah dan memperbaiki kerusakan jaringan tubuh. Menambah berat badan hingga mencapai normal dan diusahakan berat badan seimbang dengan tinggi badan (Depkes RI, 2002).

Penyakit tuberkulosis masih menjadi masalah kesehatan global dan merupakan penyebab kematian ke dua setelah HIV. Salah satu faktor yang mempengaruhi terjangkitnya penyakit $\mathrm{TB}$ adalah status gizi. Status gizi yang buruk akan meningkatkan resiko terhadap penyakit TB paru. Sebaliknya, penyakit TB paru dapat mempengaruhi status gizi penderita karena proses perjalanan penyakitnya. Oleh karena itu disarankan kepada penderita TB untuk meningkatkan pola makan dengan penganekaragaman makanan untuk memenuhi kebutuhan energinya, Untuk memenuhi kebutuhan tersebut membutuhkan perhitungan kalori makanan yang cepat dan mudah untuk membantu proses penyembuhan pada pasien yang terkena penyakit TB paru dan untuk memenuhi gizi setiap harinya.

Bertolak dari kondisi tersebut maka perlu untuk merancang suatu aplikasi yang bisa membantu masyarakat untuk menentukan pola makan yang baik bagi penderita penyakit tuberkolosis (TB). Android menjadi pertimbangan dalam mengembangkan aplikasi ini karena perangkat ini paling banyak di gunakan Masyarakat. Aplikasi ini nantinya akan digunakan oleh masyarakat penderita penyakit TB maupun Masyarakat pada umumnya untuk mengetahui pola makan yang akan di konsumsi setiap hari,

\section{A. Faktor-Faktor yang Mempengaruhi Terjadinya Penyakit Tuberkolosis Paru}

Hiswani (2009 ) mengatakan bahwa keterpaparan penyakit TBC pada seseorang dipengaruhi oleh beberapa faktor seperti:status sosial ekonomi, status gizi, umur, jenis kelamin dan factor sosial lainnya, untuk lebih jelasnya diuraikan sebagai berikut:
1) Faktor Sosial Ekonomi:

Disini sangat erat dengan keadaan rumah, kepadatan hunian, lingkungan perumahan, lingkungan dan sanitasi tempat kerjayang buruk dapat memudahkan penularan TBC. Pendapatan keluarga sangat erat juga dengan penularan $\mathrm{TBC}$, karena pendapatan yang kecil membuat orang tidak dapat layak dengan memenuhi syarat-syarat kesehatan.

\section{2) Status gizi:}

Keadaan malnutrisi atau kekurangan kalori, protein, vitamin, zat besi dan Iain-lain, akan mempengaruhi daya tahan tubuh seseorang sehingga rentan terhadap penyakit termasuk TB-paru. Keadaan ini merupakan factor penting yang berpengaruh dinegara miskin,baik pada orang dewasa maupunanak-anak.Status sosial ekonomi

\section{3) Umur:}

Penyakit TB paru paling sering ditemukan pada usia muda atau usia produktif $15-50$ tahun. Dengan terjadinya transisi demografi saat ini menyebabkan usia harapan hidup lansia menjadi lebih tinggi. Padausia lanjut lebih dari 55 tahun system imunolosi seseorang menurun, sehingga sangat rentan terhadap berbagai penyakit, termasuk penyakit TB-paru.

4) Jenis kelamin:

Penderita TB-paru cenderung lebih tinggi pada laki-laki dibandingkan perempuan. Menurut Hiswani yang dikutip dari $\mathrm{WHO}$, sedikitnya dalam periode setahun ada sekitar 1 juta perempuan yang meninggal akibat TB paru, dapat disimpulkan bahwa pada kaum perempuan lebih banyak terjadi.

Tanda dan Gejala Penyakit Tuberkolosis Paru Gejala klinis pasien Tuberkulosis Paru menurut Depkes RI (2008), adalah :

- Batuk berdahak selama 2-3 minggu atau lebih.

- Dahak bercampur darah.

- Batuk berdarah.

- Sesak napas.

- Badan lemas.

- Nafsu makan menurun.

- Berkeringat malam hari tanpa kegiatan fisik.

- Demam meriang lebih dari satu bulan.

\section{Pencegahan Penyakit Tuberkolosis Paru}

Mencegah lebih baik daripada mengobati, kata-kata itu selalu menjadi acuan dalam penanggulanagan penyakit TB-paru di masyarakat. Adapun upaya pencegahan yang harus dilakukan adalah:

a. Penderita tidak menularkan kepada orang lain ; 
1) Menutup mulut pada waktu batuk dan bersin dengan sapu tangan atau tissue

2) Tidur terpisah dari keluarga terutama pada dua minggu pertama pengobatan.

3) Tidak meludah di sembarang tempat, tetapi pada wadah yang di beri iysol, kemudia di buang ke dalam lubang dan ditimbun dalam tanah.

4) Menjemur alat tidur secara teratur pada pagi hari.

5) Membuka jendela pada pagi hari, agar rumah dapat udara bersih dan cahaya matahari yang cukup sehingga kuman tuberkolosis paru dapat mati.

b. Masyarakat tidak tertular dari penderita tuberkolosis paru:

1) Meningkatkan daya tahan tubuh,atara lain makan makanan yang bergizi.

2) Tidur dan istrahat yang cukup.

3) Tidak merokok dan tidak minum-minuman yang mengandung alcohol.

4) Membuka jendela dan mengusahakan sinar matahari masuk ke ruangan tidur dan ruangan lainya.

5) Segera periksa bila timbul batuk lebih dari tiga minggu.

6) Menjalankan perilaku hidup bersih dan sehat (PHBS).

Kebutuhan energi yang diperlukan tubuh dapat diperoleh dari asupan makanan sehari-hari. Kebutuhan energi sebaiknya diimbangi oleh asupan energi dengan jumlah yang sama (Karsin, 2004). Berdasarkan aktivitas fisik masing-masing orang, maka kebutuhan energi setiap orang akan berbedabeda pula. Khumaidi (1989) menyatakan, semakin berat aktivitas yang dilakukan, semakin banyak energi yang diperlukan untuk melakukan aktivitas tersebut. Sehingga pekerjaan yang memerlukan kekuatan fisik akan membutuhkan energi yang lebih besar dibandingkan pekerjaan yang mengandalkan keahlian (Wardani, 2008) Menaksirkan kebutuhan energi seseorang berdasarkan aktivitasnya kita perlu mengetahui kebutuhan gizi berdasarkan Angka Metabolisme Basal (AMB).

Untuk mengetahui AMB dapat dilakukan dengan beberapa cara anatara lain :

Rumus Harris -Bennedict

Laki-laki $=66,5+(13,7 \times$ BB $)+(5 \times$ TB $)+(6,8 \times$ U $)$

Perempuan $=665,1+(9,6 \times \mathrm{BB})+(1,8 \times \mathrm{TB})+(4,7$ $\mathrm{x} \mathrm{U})$

Dimana :

$\mathrm{BB}=$ Berat Badan $(\mathrm{kg})$

$\mathrm{TB}=$ Tinggi Badan $(\mathrm{cm})$
$\mathrm{U}=\mathrm{Umur}$ (tahun)

B. Aplikasi

Aplikasi berasal dari kata application yaitu bentuk benda dari kata kerja to apply yang dalam bahasa Indonesia berarti pengolah. Secara istilah, aplikasi computer adalah suatu subkelas perangkat lunak computer yang menggunakan kemampuan komputer langsung untuk melakukan suatu tugas yang diinginkan pemakai. Contoh utama perangkat lunak aplikasi adalah program pengelolah kata, lembar kerja, dan pemutar media.

C. Android

Android adalah sebuah system operasi untuk perangkat mobile berbasis linux yang mencakup system operasi, middleware dan aplikasi. Android menyiapkan API (Application Programming Interface) yang menawarkan akses ke hardware, maupun data-data ponsel sekaligus atau data system sendiri. Bahkan, pengguna dapat menghapus aplikasi inti dan dapat menggantinya dengan aplikasi pihak ketiga. (Nazaruddin Safaat H,MT,2011).

Android didirikan oleh Andy Rubin, Rich Miner, Nick Sears dan Chris White pada tahun 2003,yang pada akhirya diambil alih keseluruhanya pada tahun 2005 oleh google. Android pun dapat dikatakana mulai mengusai pasar global saat ini dan mengalahkan Symbian yang terkenal di masa sebelumnya.

Secara garis besar system operasi android menjadi 5 tingkatan:

\section{a). Linux Kernel}

Linux Kernel adalah kernel dasar dari android. Tingkat ini berisi semua drive perangkat tingkat rendah untuk komponen-komponen perangkat android .

\section{b). Libraries}

Libraries berisi semua program yang menyediakan layanan-layanan utama untuk system operasi android.

\section{c). Android Runtime}

Android runtime kedudukanya sama dengan libraries,android runtime menyediakan kumpulan pustaka inti yang dapat diaktifkan oleh pengembang untuk menulis kode aplikasi dengan bahasa pemrograman java. Arsitektur android yang diggunakan dapat di lihat pada gambar 1.

d). Application Frame work 


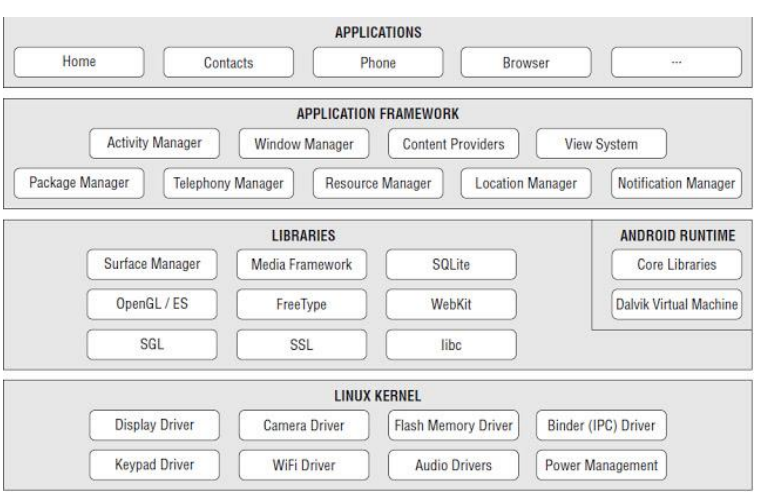

Gambar 1. Artitektur Android, (Chris White pada tahun 2003)

Sumber:(https://widuri.raharja.info/index.php/SI1122466910)

Application framework adalah semacam kumpulan class build in yang tertanam dalam system operasi android sehingga pengembang dapat memanfaatkannya untuk aplikasi yang sedang di bangun.

\section{e). Applications}

Tingkat di mana proses pengerjaan pembuatan aplikasi dilakukan.

Android disebut sebagai "platform mobile pertama yang lengkap, terbuka, dan bebas" Android memiliki arsitektur system sebagai berikut

\section{Eclipse IDE}

Eclipse adalah sebuah IDE (Integrated Development Environment) untuk mengembangkan perangkat lunak dan dapat dijalankan di semua platform (platformIndefendent).

\section{E. Android SDK}

Android SDK adalah tools API (Application Programming Interface) yang diperlukan untuk mulai mengembangkan aplikasi pada platform Android menggunakan bahasa pemrograman Java. Android merupakan subset perangkat lunak untuk ponsel yang meliputi sistem operasi, middleware dan aplikasi kunci yang di-release oleh Google. Saat ini disediakan Android SDK (Software Development Kit) sebagai alat bantu dan API untuk mulai mengembangkan aplikasi pada platform Android menggunakan bahasa pemrograman Java. Sebagai platform aplikasi netral Android memberi anda kesempatan untuk membuat aplikasi yang kita butuhkan yang bukan merupakan aplikasi bawaan Handphone atau Smartphone.

\section{F. Java}

Java merupakan bahasa pemrograman yang dikembangkan dari bahasa pemrograman $\mathrm{C}++$. Berawal dari proyek penelitian perusahaan Sun Microsystems dengan nama sandi green pada tahun 1991. Terdapat prediksi bahwa mikroposesor akan digunkan luas pada peralatan-peralatan elektronik..

\section{G. Metode RAD}

Dalam metode RAD terdapat langkah-langkah yang dibagi dalam empat fase. Langkah-langkah metode RAD dapat di lihat pada gambar 2.

1. Fase Analis Persyaratan

Fase ini memiliki tujuan untuk mengidentifikasi layanan, batasan, dan obyektifitas dari sistem dari pengumpulan data yang dilakukan terhadap stakeholders. Selain itu analisis persyaratan juga bertujuan untuk mendefinisikan persyaratan user dan sistem. Hasil akhir dari analisis persyaratan yaitu spesifikasi awal dari persyaratan user dan sistem. Adapun Fase 1 ini terdiri dari Komunikasi dan Perancangan proyek, Studi kelayakan, Spesifikasi pengguna dan Spesifikasi system.

2. Fase Analisis Modeling

Tujuan dari fase analisis modeling adalah menganalisis semua kegiatan dalam arsitektur sistem secara keseluruhan dengan melibatkan identifikasi dan deskripsi abstraksi sistem perangkat lunak yang mendasar dan hubunganhubungannya. Selain itu, analisis modeling juga bertujuan untuk meningkatkan pemahaman terhadap permasalahan tanpa mempertimbangkan solusi teknis. Hasil akhir dari analisis modeling yaitu diagram model logis dari sistem yang sedang berjalan, diantaranya use case diagrams, class diagram, dan sequence diagrams. Fase 2 ini terdiri dari: Identifikasi pelaku bisnis, Analisis proses dan kerja system dan Mengidentifikasi struktur objek dan realisasi.

3. Fase Desain Modeling

Tujuan dari fase desain modeling yaitu melakukan perancangan sistem berdasarkan analisis yang telah dilakukan sebelumnya. Tahap analisis dan desain mengalami perulangan hingga diperoleh rancangan sistem yang benar-benar memenuhi kebutuhan. Selain itu, fase 3 ini juga bertujuan untuk memberikan spesifikasi yang jelas dan lengkap kepada programmer dan teknisi. Hasil akhir dari fase ini yaitu basis data, antarmuka, dan spesifikasi desain. Fase 3 ini terdiri dari: Memodelkal kembali diagram use case untuk mereflesikan 


\section{RAD Design Workshop}

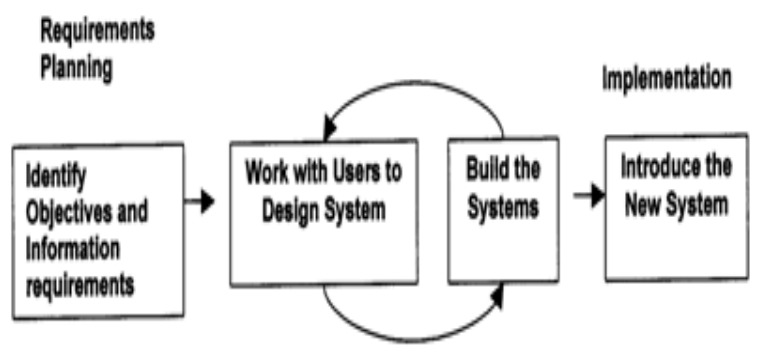

Gambar 2 Tahapan RAD (Gerber, 2007)

Sumber:(http://digilib.mercubuana.ac.id/manager/n! @ file_skripsi/Isi2434084841215.pdf)

lingkungan implementasi, Memodelkan interaksi objek dan behviours, Desain antar muka, dan Membuat algoritma.

4. Fase Konstruksi

Tujuan dari fase konstruksi adalah untuk menunjukkan platform, hardware dan software yang digunakan serta batasan dalam implementasi, serta menguji performansi prototipe perangkat lunak yang telah dibangun agar dapat diketahui apakah prototipe tersebut telah sesuai dengan spesifikasi analisis dan perancangan yang telah diidentifikasi sebelumnya. Hasil akhir dari fase konstruksi adalah platform, hardware dan software yang digunakan, serta daftar batasan implementasi, dan rencana pengujian. Fase 4 ini terdiri dari: Lingkungan implementasi, Implementasi basis data, Melakukan pemrograman, Implementasi antarmuka Pengujian

\section{5) METODOLOGI PENELITIAN}

Analisis merupakan kajian terhadap hal -hal yang berkaitan dengan detail atau struktur pembangunan perangkat lunak. Tahap analisis merupakan tahap yang penting, karena ini adalah tahap pertama dalam suatu perencanaan. Apabila terjadi kesalahan, maka akan menyebabkan kesalahan ditahap-tahap selanjutnya. Oleh karena itu, dibutuhkan suatu metode yang dapat digunakan sebagai pedoman dalam pengembangan suatu aplikasi.

Metode analisis ini diperlukan berkaitan dengan perancangan suatu sistem yang akan dibuat dan berhubungan dengan hasil yang ingin dicapai oleh sistem tersebut. Metode analisis digunakan setelah mengetahui tujuan dan persoalan apa yang ingin dipecahkan. Analisis awal dengan melakukan analisis kebutuhan antarmuka. Dari analisis tersebut dapat diketahui apa saja yang akan menjadi kebutuhan masukan. Setelah mendapatkan kebutuhan masukan, maka dapat dibayangkan proses yang akan berjalan sehingga mendapatkan kebutuhan keluaran sesuai yang diharapkan.

Secara garis besar, gambaran sistem yang akan dibuat bertujuan untuk memudahkan pengguna dalam menggunakan alat penghitung kalori ini, sehingga pengguna tidak perlu menghitung jumlah jumlah kalorinya secara manual. Ada beberapa analisis yang dibutuhkan untuk menyelesaikan masalah tersebut. Analisis-analisis tersebut adalah:

- Analisis Kebutuhan Antarmuka

- Analisis Kebutuhan Masukan

- Analisis Kebutuhan Proses

- Analisis Kebutuhan Keluaran

perancangan aplikasi yang diciptakan untuk efisiensi waktu dalam pengembangan aplikasi. Model RAD ini memungkinkan developer menciptakan aplikasi dalam waktu singkat karena menggunakan pendekatan konstruksi berbasis komponen. Sehingga, kebutuhan sistem mampu dipahami dengan baik. Fase-fase dalam RAD terdapat bentuk seperti use case, diagram sederhana,dan diagram rinci yang bertujuan untuk memberikan pengertian dalam alur jalannya program. (Gerber, 2007)

\section{Use Case Diagram}

use case merupakan pemodelan fungsi yang menjabarkan fungsi yang bisa digunakan oleh pengguna terhadap aplikasi tersebut. Use case diagram dapat di lihat pada gambar 4.

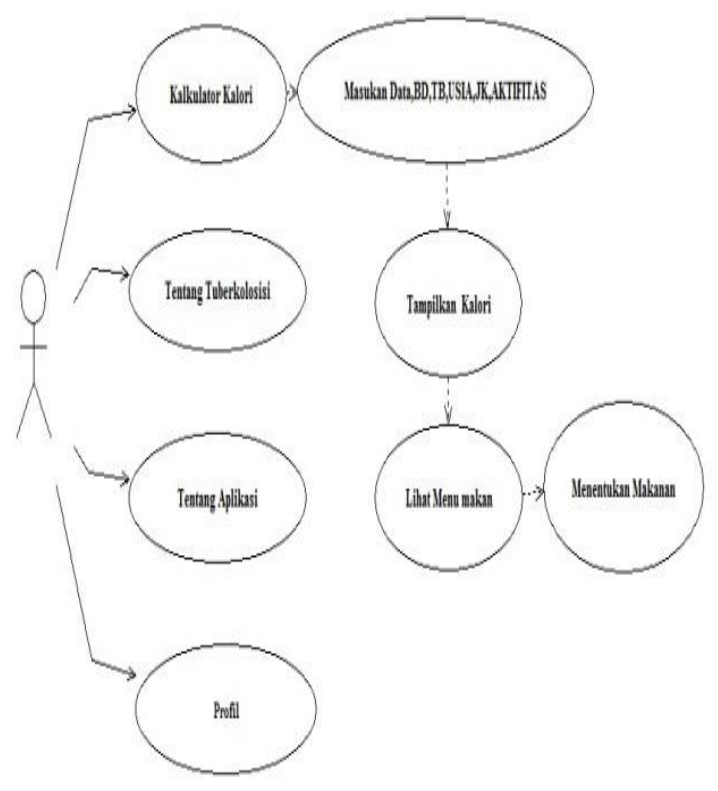

Gambar 4. Use Case Diagram 


\begin{tabular}{|c|c|c|}
\hline inoputit & proses & Output \\
\hline $\begin{array}{l}\text { 1.masukan } \\
\text { data } \\
\text { penggun } \\
\text { a } \\
\text { 2. menentu } \\
\text { kanan } \\
\text { menu } \\
\text { makanan } \\
\text { sesuai } \\
\text { dengan } \\
\text { kebutuha } \\
\text { n kalori } \\
\text { 3. menekan } \\
\text { tombol } \\
\text { centang }\end{array}$ & $\begin{array}{c}\text { Aplikasi } \\
\text { mulai } \\
\text { bekerja } \\
\text { dengan } \\
\text { menghit } \\
\text { ung } \\
\text { kalori }\end{array}$ & $\begin{array}{l}\text { Aplikasi } \\
\text { menampilk } \\
\text { an jumlah } \\
\text { kalori } \\
\text { pengguna } \\
\text { aplikasi } \\
\\
\text { Aplikasi } \\
\text { menampilk } \\
\text { an } \\
\text { makanan } \\
\text { yang di } \\
\text { konsumsi } \\
\text { pengguna } \\
\text { aplikasi }\end{array}$ \\
\hline
\end{tabular}

Gambar 5 Gambar Diagram Sederhana

\section{Diagram Sederhana}

Diagram ini merupakan diagram yang menjelaskan fungsi dan referensi utama yang diperlukan dalam program detail untuk memperluas fungsi sehingga cukup rinci. Diagram ini berisi Input, proses serta output. Dibagian Input berisi masukanmasukan yang selanjutnya akan dieksekusi pada bagian proses. Dibagian proses berisi urutan langkahlangkah yang menjelaskan fungsi yang sedang dijalankan. Tanda anak panah antara keduanya menghubungkan masukan data Input dengan langkah-langkah pada tahap Proses. Bagian output berisi hasil atau keluaran data yang dihasilkan

dari tahap Proses. Tanda anak panah yang berikutnya menghubungkan tahap-tahap Proses dengan item data output.

Suatu penjelasan yang telah diperluas juga dimasukkan kedalam diagram ringkasan sehingga dapat mempermudah dalam memahami alur tahapan dari Input, Proses, hingga Output

\section{HASIL DAN PEMBAHASAN}

Pada Bab ini, seluruh hasil penelitian perancangan aplikasi pemenuhan gizi melalui pola makan, lebih khususnya pada penderita penyakit TB paru akan di bahas, mulai dari analisa persyaratan, analisa modeling fase konstruksi

A. Analisa Persyaratan
Tahap ini bertujuan untuk mengidetifikasi kebutuhan, objek, dan spesifikasi system melalui pengumpulan data yang di lakukan pada pengguna dan untuk mengetahui persyaratan pengguna sistem yang akan di buat.

Di tahap ini dilakukan identifikasi dan menetapkan kebutuhan pengguna. Tahap ini adalah untuk mengidentifikasi target pengguna

Tabel 1. Identifikasi pengguna

\begin{tabular}{lllr}
\hline & Aktor & \multicolumn{2}{c}{ Tanggung Jawab } \\
\hline 1 & Pengguna & 1.1. & Menggunakan \\
& Aplikasi/User & aplikasi r untuk \\
& & pemenuhan & gizi \\
& & melalui pola makan \\
& & lebih khususnya pada \\
& & penderita penyakit \\
& & TBC paru & \\
\hline
\end{tabular}

\section{B. Analisa Modeling}

Pada tahap ini akan dilakukan analisa terhadap semua kegiatan yang terjadi pada system yang sedang bejalan. Analisa pemodelan ini akan menngunakan tols UML (Unified Modelling Language).

Activity Diagram menjelaskan tentang aktifitasaktifitas secara berurutan yang akan di lakukan pada aplikasi pemenuhan gizi melalui pola makan pada pederita penyakit tuberkolosis paru.

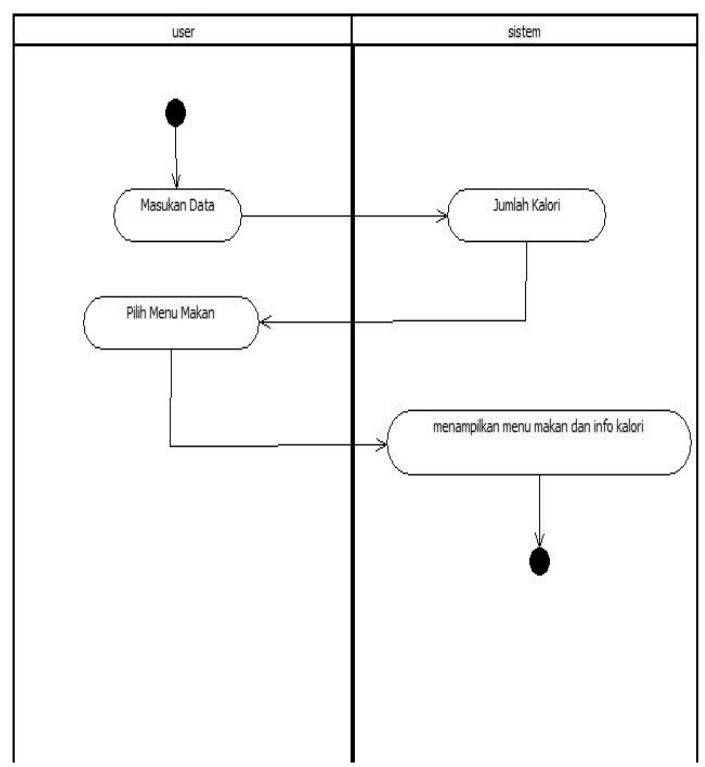

Gambar 6. Activity Diagram 


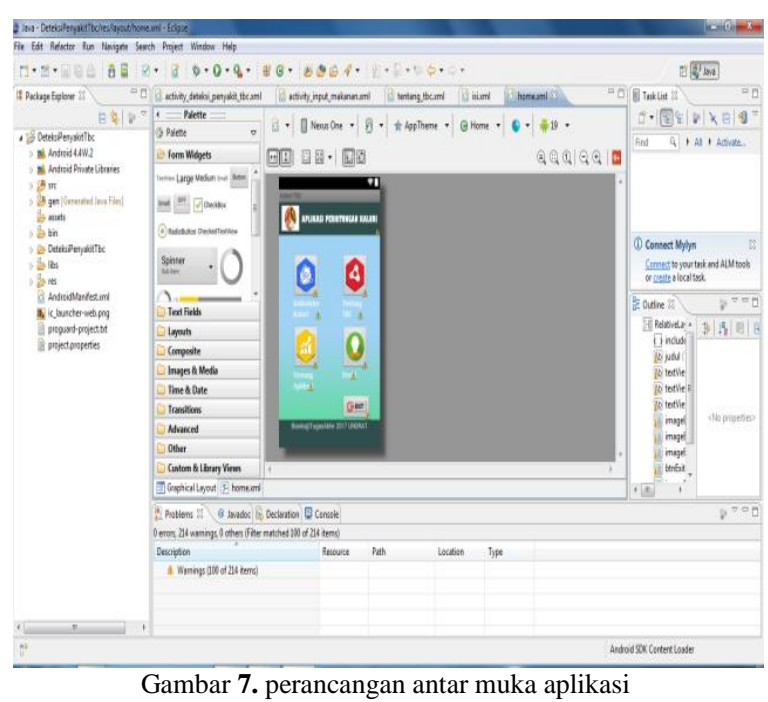

Gambar 7. perancangan antar muka aplikasi

Pada bagian ini, pengembang melakukan perancangan antar muka program melalui aplikasi eclips. Di mana di bagian kiri layar terdapat serangkaian package explorer yang didalamnya terdapat bagian-bagian yang di antaranya adalah srs, gen (generated java files), deteksi penyakit tbc, res, pilih pengaturan layout. Dan lain sebagainya

Gambar di bawah adalah ilustrasi implementasi aplikasi yang berjalan oleh seorang pengguna yakni aplikasi di mulai dengan tampilan awal pada Gambar 8a, terdapat 5 button menu yaitu menu "Kalkulator kalori", "Tentang TBC", "Tentang aplikasi", "Profil", dan tombol "Exit". Untuk memulai melihat daftar makanan penderita panyakit TBC paru memilih menu "kalkulator kalori" lalu mulai memasukan data user kemudian menampilkan perhitungan kalori (lihat Gambar 8b), selanjutnya memilih salah satu tombol untuk masuk dan memilih waktu makan (lihat Gambar 8c).

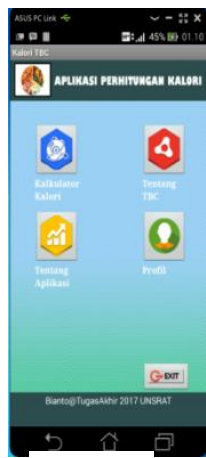

a

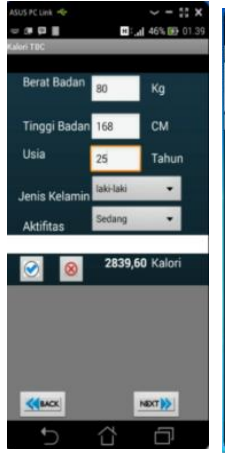

b

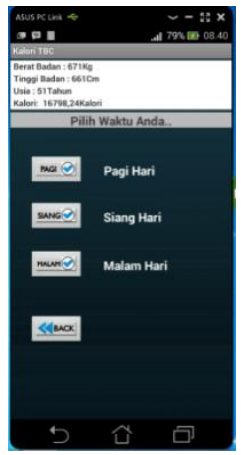

(c)
Gambar 8 Tampilan Aplikasi. (a) Gambar Tampilan Awal Aplikasi , (b)Gambar Tampilan Perhitungan Kalori, (c) Gambar Tampiln memilih Waktu makan

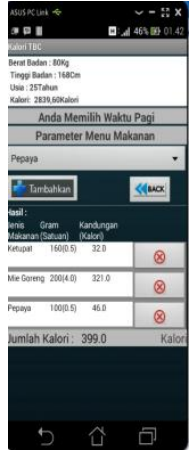

(a)pagi,

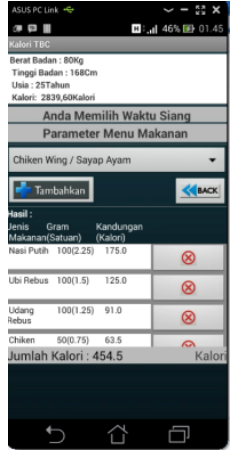

(b) siang,

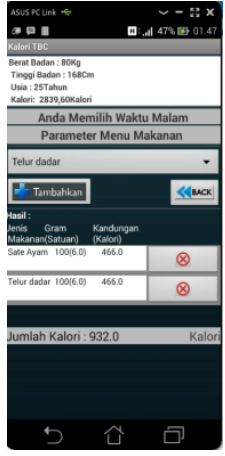

(c) malam.
Gambar 9 Tampilan informasi, (a) Gambar tampilan pagi, (b) Gambar Tampilan Siang, (c) Gambar Tampilan malam

Mesin inferensi kemudian memberikan informasi yang telah di tarik kesimpulan dari data yang telah diolah dan kemudian pengguna atau user dapat melihat informasi tersebut. Informasinya berupa komposisi makanan untuk memenuhi kalori pengguna (user). Untuk melihat dan menambah waktu makanan dapat dilihat pada gambar 9

\section{KESIMPULAN DAN SARAN}

\section{A. Kesimpulan}

Kesimpulan akhir dari pembuatan aplikasi pemenuhan gizi melalui pola makan pada penderita penyakit TB paru berbasis android adalah sebagai berikut:

1. Dengan adanya aplikasi ini dapat membantu efisiensi waktu dalam memperoleh informasi makanan dengan nilai kalorinya untuk masyarakat dan lebih khususnya yang mengalami penyakit TBC paru.

2. Metode Rapid Application Development (RAD) dapat digunakan untuk membangun aplikasi berbasis android. Aplikasi ini juga dapat ini juga dapat berjalan dengan baik pada semua perangkat android.

\section{B. Saran}

Apabila kedepannya ada yang ingin mengembangkan penelitian ini lebih lanjut, disarankan untuk membuat lebih baik lagi dan untuk pengembang selanjutnya agar dibuatkan versi aplikasi dengan sistem operasi iOS (iphone Operating System) untuk aplikasi ini. 


\section{DAFTAR PUSTAKA}

[1] F Putri D, R, F.S. Kom, M.Si. Jurnal Skripsi."Sistem Informasi Pemenuhan Gizi Melaui Menu Makanan Menggunakan Metode Cooper Berbasis Website

[2] M. L Kasenda. Sistem monitoring kognitif,afektif, dan psikomotor siswa berabasis android. 2016

[3] R.J.M Mandagi,. dkk. Paduan Penulisan KTIS. Tim Penyusun Paduan Penulisan KTIS Fakultas Teknik Unsrat, Manado.2006

[4] A. Noertjahyana. Studi Analisa Rapid Application Development Sebagai Salah Satu Alternatif Metode Pengembangan Perangkat Lunak. Jurnal Informatika, Vol. 3, No. 2. 2002

[5] R.S. Pressman,.. Rekayasa Perangkat Lunak buku 1. Edisi7, terjemahan timpenerjemah andi, Yogyakarta: Andi.2010

[6] Rahmawati,F, M, Penentuan Kecukupan Energi

[7] E. Tulutono, "Pola Makan Penderita Tuberkolosis Paru Di Wilayah Kerja Puskesmas Banggai Kecamatan Banggai Kabupaten Banggai Laut”.2014

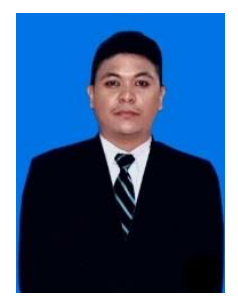

Sekilas dari penulis dengan nama lengkap Bianto Aluano, lahir di Adean Kabupaten Banggai Laut Profinsi Sulawesi Tengah. Anak tunggal dengan pendidikan Sekolah Dasar Inpres Adean. Penulis lalu melanjutkan ke Sekolah Menengah Pertama Negeri 2 Banggai. Lalu ke SMA Negri 1 Banggai. Pada tahun 2011 melanjutkan ke Perguruan Tinggi di Universitas Sam Ratulangi dengan mengambil Jurusan Teknik Informatika. Pada Tahun 2017 bulan September, penulis membuat Skripsi demi memenuhi syarat Sarjana (S1) dengan penelitian berjudul Aplikasi Pemenuhan Gizi Melalui Pola Makan Pada Penderita Tuberkolosis paru berbasis android di Universitas Sam Ratulangi yang dibimbing oleh dua dosen pembimbing yaitu Yaulie D. Y. Rindengan, ST,MM,MSc dan Alwin M. Sambul, ST.,M.Eng.,Ph.D sehingga pada tanggal 18 Oktober 2017 penulis resmi lulus di Teknik Informatika Universitas Sam Ratulangi Manado menyandang gelar sarjana komputer dengan predikat sangat memuaskan. 